Movere Journal Vol 1 No. 1 Januari 2019 Hal 1-13

MOVERE JOURNAL

http://ojs.stie-tdn.ac.id/index.php/mv

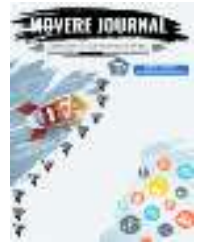

\title{
PENGARUH TAGLINE IKLAN VERSI "AXIS HITS BONUS" DAN BRAND AMBASSADOR TERHADAP BRAND AWARENESS KARTU AXIS (STUDI PADA MAHASISWA STIE AMKOP MAKASSAR)
}

\author{
Abdul Karim \\ STIE AMKOP Makassar
}

\begin{abstract}
Abstrak : Penelitian ini bertujuan untuk mengetahui pengaruh tagline iklan versi "Axis Hits Bonus" dan brand ambassador secara parsial maupun secara simultan terhadap brand awareness kartu Axis pada mahasiswa STIE AMKOP Makassar. Penelitian ini menggunakan penelitian explanatory research. Sampel dalam penelitian ini sebanyak 96 orang mahasiswa STIE AMKOP Makassar yang ditentukan dengan menggunaka rumus Paul Leedy. Teknik pengumpulan data yang digunakan adalah melalui penyebaran kuesioner dan dokumentasi dari data primer dan data sekunder.
\end{abstract}

Kata kunci: tagline iklan, brand ambassador dan brand awareness

\section{PENDAHULUAN}

AXIS merupakan salah satu penyedia layanan telekomunikasi berbasis GSM hadir di Indonesia. Dengan didukung oleh dua operator terkemuka di Asia: Saudi Telecom Company, penyedia layanan telekomunikasi nasional Arab Saudi; dan MAXIS Communications Berhad, penyedia layanan telekomunikasi di Malaysia, AXIS berusaha mengembangkan bisnisnya di Indonesia. Dengan populasi penduduk di Indonesia yang mencapai lebih dari 200 juta jiwa merupakan potensi pasar yang sangat menjanjikan untuk diolah. Namun demikian bukan hal yang mudah terutama dengan kondisi seperti sekarang ini dimana di Indonesia sudah banyak terdapat penyedia layanan telekomunikasi, sehingga diperlukan usaha yang ekstra agar mampu bersaing dengan produk competitor yang sudah ada. Saat ini untuk penyedia layanan telekomunikasi selular berbasis GSM di Indonesia dikuasai tiga perusahaan besar yaitu TELKOMSEL dengan produknya Simpati dan Kartu AS, INDOSAT dengan produknya Mentari dan IM3 serta EXCELKOMINDO dengan produknya XL.

Berbagai program baru dihadirkan AXIS dan dikemas sedemikian rupa dalam iklannya di media televisi. Berbeda dengan competitor, AXIS setiap bulannya tidak hanya menampilkan satu atau dua iklan saja, namun setidaknya menampilkan lebih dari tiga macam iklan. Selain itu, program yang ditawarkan AXIS pada iklan di televisi juga beragam dan merupakan terobosan baru karena operator lain belum ada yang memberikan program sejenis. Adapun iklan-iklan AXIS yang ditayangkan di Televisi dengan menggunakan selebrity endorser antara lain; "Cak Norris (Axis Super Hemat, Gratis SMS ke semua operator)", "AXIS Internet Gaol", "Irotology (Irit itu AXIS, Gaya Hidup Irit)", "Cilok Cinlok (AXIS 
Juara Iritnya, AXIS KZL)", "Parody Goblin (Nelpon, Chating, Video Call Sepuasnya Setiap Hari)", dan yang terakhir tahun 2017 adalah " AXIS Hits Bonus".

Dalam bidang komunikasi pemasaran, tagline atau selogan dan brand ambassador memang kerap sekali dingunakan perusahaanperusahaan dalam mempromosikan produk-produk yang akan dilempar ke pasaran, namum seberapa efektif dan efisien strategi ini masih belum pasti karena banyak perusahaan yang tetap tidak bisa meningkatkan brand awareness masyarakan akan produknya. Ada juga beberapa penelitian yang menganggap bahwa kedua variabel tersebut tidak memiliki pengaruh yang signifikan terhadap brand awareness konsumennya.

Banyaknya tagline yang ada pada iklan-iklan di media cetak maupun elektronik juga kerap membuat konsumen sulit untuk menghafal dan membedakan antara tagline produk satu dengan yang lain. AXIS pun termasuk dalam satu dari sekian banyak produk yang menggunakan tagline pada iklanya, namun apakah tagline kartu AXIS bisa diingat oleh konsumen, bahkan dapat meningkatkan brand awareness konsumen.

\section{TINJAUAN TEORI}

\section{Konsep Umum Periklanan (Advertising)}

Periklanan merupakan salah satu dari empat alat utama yang digunakan oleh perusahaan untuk mengarahkan komunikasi yang meyakinkan kepada sasaran pembeli dan publik. Periklanan adalah komunikasi non-individu dengan sejumlah biaya dengan berbagai media yang dilakukan oleh perusahaan, lembaga non-laba, serta individu-individu (Swastha dan Irawan, 2010:245). Periklanan dapat dipandang sebagai kegiatan penawaran kepada suatu kelompok masyarakat baik secara lisan ataupun dengan penglihatan (berupa berita), tentang suatu produk, jasa, atau ide. Berita yang disampaikan tersebut dinamakan iklan atau advertensi.

Tujuan periklanan yang utama adalah menjual atau meningkatkan penjualan barang, jasa, atau ide. Adanya kegiatan periklanan sering mengakibatkan terjadinya penjualan dengan segera meskipun banyak juga penjualan yang baru terjadi pada waktu mendatang. Dari segi lain periklanan yang riil adalah mengadakan komunikasi secara efektif. Menurut (Swastha dan Irawan, 2010:252) tujuan lain dari periklanan adalah:

1) Mendukung program personal selling dan kegiatan promosi lain.

2) Mencapai orang-orang yang tidak dapat dicapai oleh tenaga penjualan ataupun salesman dalam jangka waktu tertentu.

3) Mengadakan hubungan dengan para penyalur, misal dengan mencantumkan nama dan alamatnya.

4) Memasuki daerah pemasaran baru atau menarik pelanggan baru.

5) Memperkenalkan produk baru.

6) Menambah penjualan industri.

7) Mencegah timbulnya barang-barang tiruan.

8) Memperbaiki reputasi perusahaan dengan memberikan pelayanan umum melalui periklanan.

Pemasaran bertujuan memberitahu serta memberi petunjuk kepada pembeli potensial dan untuk meningkatkan penjualan.

\section{Sasaran Periklanan}

Dalam memasang iklan hendaknya tidak semata-mata mempertimbangkan yang akan menjadi sasarannya, tetapi juga perlu dipertimbangkan pihakpihak yang mungkin berhubungan dengan iklan dan sasarannya. Menurut 
(Sigit, 2010:51) iklan sebaiknya disusun dengan memperhatikan beberapa hal yaitu:

1) Para pembeli dan pemakai diwaktu sekarang.

2) Mereka yang memilki potensi sebagai pembeli.

3) Mereka yang memilki kekuasaan memutuskan membeli.

4) Mereka yang menjadi pembeli atau pemakai diwaktu yang akan datang.

5) Mereka yang dapat dipengaruhi orang lain untuk membeli atau memakai.

6) Pasar pedagang.

7) Pasar pesaing.

\section{Fungsi Periklanan}

Investasi besar-besaran ini menunjukan bahwa banyak perusahaan yang memiliki keyakinan akan efektifitas periklanan. Secara umum, periklanan dihargai karena dikenal sebagai pelaksana beragam fungsi komunikasi, fungsinya antara lain:

1) Informing (memberi informasi)

2) Persuasing (mempersuasi)

3) Reminding (mengingatkan)

4) Adding value (memberi nilai tambah)

5) Assisting (mendampingi)

\section{Tagline Iklan}

Tagline atau slogan merupakan bagian dari iklan yang bertujuan agar iklan tersebut mudah diingat oleh konsumen. Tagline dalam suatu iklan memegang peranan penting. Menurut Nuradi dkk. (2012: 56) tagline adalah kalimat singkat sebagai penutup teks inti yang menyimpulkan secara singkat tujuan komunikasi suatu iklan. Tagline merupakan suatu ungkapan pendek berisi pesan yang padat dan mudah diingat. Tagline ini bisa disamakan dengan slogan, atau jargon dalam iklan. Penggunaan tagline ini adalah untuk memperkuat kemampuan iklan dalam mengeksekusi (mencapai sasarannya) yaitu mempengaruhi konsumen untuk menggunakan produk yang diiklankan.

Dengan adanya tagline dalam sebuah iklan, maka akan sangat membantu masyarakat untuk mengingat merek dari produk yang ditawarkan. Jadi tagline merupakan sederetan kalimat atau ungkapan kreatif yang mudah diingat dan mampu mempresentasikan keseluruhan pesan iklan dari perusahaan kepada konsumen atau masyarakat, yang meliputi merek dan karakter produknya, dalam rangka proses penanaman konsep terhadap produk secara positif ke dalam benak masyarakat.

Tagline dapat digunakan untuk membantu mengomunikasikan titik pembeda dari pesaing. (Susanto dan Wijanarko, 2014: 86). Tagline ini bisa berubah sesuai dengan perubahan situasi dan kondisi, maupun sebagai strategi agar konsumen tidak bosan. Pengenalan tagline baru biasanya dilakukan melaluin program above the line (ATL) berupa penayangan iklan diberbagai media massa cetak dan elektronik.

\section{Brand Ambassador}

Brand Ambassador adalah istilah pemasaran untuk seseorang yang dipekerjakan oleh sebuah organisasi atau perusahaan untuk mempromosikan produk atau jasa dalam kegiatan yang dikenal sebagai branding. Brand ambassador dimaksudkan untuk mewujudkan identitas perusahaan dalam penampilan, sikap, nilai-nilai dan etika Menurut Shimp (2003:455) brand ambassador adalah pendukung iklan atau juga yang dikenal sebagai bintang iklan yang mendukung produk yang diiklankan. Para brand ambassador diharapkan menjadi juru bicara merek agar cepat melekat di benak konsumen, sehingga konsumen 
mau membeli merek tersebut. Selain itu, selebriti bisa juga digunakan sebagai alat yang tepat untuk mewakili segmen pasar yang dibidik. Oleh sebab itu tidak heran ketika produk yang diiklankan menggunakan banyak selebriti, masing-masing akan mewakili segmen pasar yang dibidik. (Royan, 2014:122).

\section{Brand Awareness}

Dalam dunia pemasaran modern, manajemen perusahaan tidak cukup hanya memfokuskan diri untuk membuat suatu produk dengan brand platform atau landasan merek yang kokoh, tetapi juga perlu menetapkan suatu harga dan nilai lebih untuk suatu merek, serta membuatnya terjangkau bagi pasar sasaran. Iklim persaingan yang ketat membuat manajemen pemasaran harus mampu membuat merek dari produk mereka dapat dikomunikasikan pada pasar sasaranya. Secara umum, komunikasi suatu merek memiliki tiga tujuan utama yaitu:

1) Membangun serta meningkatkan brand awareness.

2) Memperkuat, memperjelas dan mempercepat pesan suatu merek.

3) Menstimulasi dan memotivasi target konsumen untuk melakukan aksi pembelian.

Brand awareness adalah kesanggupan seseorang calon pembeli untuk mengenali atau mengingat bahwa suatu merek merupakan bagian dari kategori produk tertentu (Aaker, 2011:51). Top of mind (puncak pikiran) apaila responden ditanya secara langsung tanpa diberi bantuan pengingatan dan ia dapat menyebutkan satu nama merek, maka merek yang pertama kali disebutkan merupakan puncak pikiran. Pelanggan secara otomatis akan mampu menguraikan elemen-elemen merek tanpa harus dibantu (Sadat, 2009).

\section{METODE PENELITIAN}

\section{Desain dan Pendekatan Penelitian}

Bedasarkan tingkat ekplanasinya, penelitian ini digolongkan ke dalam penelitian asosiatif kasual. Penelitian asosiatif kasual merupakan penelitian yang mencari hubungan atau pengaruh sebab akibat yaitu hubungan atau pengaruh variabel bebas (X) terhadap variabel terikat (Y) (Sugiyono, 2012:38).

Sugiyono (2012:38) mengemukakan penelitian asosiatif kasual adalah penelitian yang akan mengkaji pengaruh antara variabel independen dengan variable dependen, yang dalam penelitian ini menguji bagaimana pengaruh antara tagline iklan dan brand ambassador terhadap brand awareness pada mahasiswa STIE AMKOP Makassar, penggunaan Kartu AXIS.

Pendekatan penelitian yang digunakan pada penelitian ini adalah pendekatan kuantitatif yang didukung oleh pendekatan kualitatif. Penelitian dengan pendekatan kuantitatif menurut Azwar (2012:35) adalah penelitian yang menekankan pada analisis data numerikal atau angka dengan metode statistika. Secara mendasar pendekatan kuantitaif dilakukan pada penelitian inferensial untuk menguji hipotesis serta menyandarkan hasil penelitian melalui probabilitas kesalahan penolakan hipotesis nihil. Sedangkan pendekatan kualitatif digunakan untuk mendeskripsikan karakteristik responden dan variabel penelitian.

\section{Populasi, Sampel, dan Teknik Sampling}

Populasi adalah gabungan dari seluruh elemen yang berbentuk peristiwa, hal atau orang yang memiliki karakteristik yang serupa yang menjadi pusat perhatian seorang peneliti karena itu dipandang sebagai sebuah semesta penelitian (Ferdinand, 2006:223). Populasi pada penelitian ini 
adalah mahasiswa STIE AMKOP Makassar yang menggunakan kartu AXIS (termasuk mahasiswa program S1 dan S2). Hal ini dikarenakan STIE AMKOP Makassar merupakan salah satu tempat dimana banyak mahasiswa muda yang masih berjiwa muda yang menggunakan telepon seluler yang sesuai dengan target pasar AXIS.

Sampel adalah bagian dari populasi yang dipilih melalui cara tertentu yang mewakili karakteristik tertentu, jelas dan lengkap yang dianggap mewakili populasi (Arifin, 2012:55). Rumus yang digunakan untuk menentukan jumlah sampel adalah rumus Paul Leedy.

Model Paul Leedy menurut Arifin (1012:55) digunakan jika populasi penelitian merupakan sebuah proporsi atau bagian dari kelompok populasi lain yang lebih besar ukurannya, seperti misalnya populasi berupa jumlah keluarga miskin disuatu daerah, dimana keluarga miskin merupakan bagian dari jumlah KK yang ada di daerah tersebut yaitu:

$$
\mathrm{n}=\underset{\mathrm{e}}{\left.\stackrel{\mathrm{Z}^{2}}{----}\right)(\mathrm{P})(1-\mathrm{P})}
$$

Keterangan :

$\mathrm{n}=$ ukuran sampel

$\mathrm{P}=$ proporsi harus dalam populasi

$\mathrm{e}=$ sampling error $(10 \%)$

$\mathrm{Z}=$ standar kesalahan yang dipilih

Jumlah populasi dalam penelitian ini tidak diketahui, maka nilai $\mathrm{P}$ maksimal $=0,25 \%$. Bila menggunakan confidance level $95 \%$ dengan tingkat kesalahan $10 \%$, maka besarnya sampel adalah :

$$
\mathrm{n}=\left[\begin{array}{c}
1,96 \\
0,----
\end{array}\right]^{2} \quad 0,25=96,4
$$

Teknik pengambilan sampel untuk menentukan sampel yang akan digunakan dalam penelitian ini menggunakan non probability sampling, yaitu purposive sampling. Purposive sampling adalah cara pengambilan sampel yang membatasi pada ciri-ciri khusus seseorang yang memberikan informasi yang diperoleh dapat lebih terfokus dan sesuai dengan yang diinginkan peneliti. Kriteria yang digunakan ialah :

1. Mahasiswa yang pernah mendengar tagline "Axis Hits Bonus"

2. Mahasiswa yang pernah melihat bintang iklan Kartu Axis oleh versi "Axis Hits Bonus".

\section{Instrumen Penelitian}

Adapun instrumen penelitian yang digunakan pada penelitian ini yang berfungsi sebagai alat pengumpul data adalah angket atau kuesioner. Angket yaitu suatu teknik pengumpulan data dengan menggunakan seperangkat daftar pertanyaan yang telah disusun dan kemudian disebarkan kepada responden untuk memperoleh data yang diperlukan, atau sejumlah pertanyaan tertulis yang digunakan untuk memperoleh informasi dari responden dalam arti laporan tentang pribadinya, atau hal-hal yang ia ketahui (Arikunto, 2010:101).

Kuesioner sebagai alat pengumpul data digunakan untuk mendapatkan informasi yang berkenaan dengan pendapat, aspirasi, harapan, persepsi, keinginan, keyakinan, dan lain-lain dari individu/responden. Caranya, melalui pertanyaan-pertanyaan yang sengaja diajukan kepada individu oleh peneliti.

Skala pengukuran instrumen adalah kesepakatan yang digunakan sebagai acuan pendeknya interval yang ada dalam alat ukur, sehingga alat ukur tersebut bila digunakan akan meghasilkan data kuantitatif. Dalam penelitian ini skala pengukuran yang digunakan adalah skala Likert, yaitu skala yang digunakan untuk mengukur 
pendapat orang atau sekelompok orang tentang fenomena sosial, penulisan analisis kuantitatif menggunakan pernyataan dan skor sebagai berikut

1) Skor 5 untuk jawaban sangat setuju (SS)

2) Skor 4 untuk jawaban setuju (S)

3) Skor 3 untuk jawaban netral (N)

4) Skor 2 untuk jawaban tidak setuju (TS)
5) Skor 1 untuk jawaban sangat tidak setuju (STS)

\section{Definisi Operasional}

Definisi operasional menjelaskan bagaimana variabel penelitian dapat diukur atau dioperasionalkan. Adapun variabel yang dilteliti oleh penulis dapat dilihat pada tabel 1 berikut :

Tabel 1

Definisi Operasional Variabel

\begin{tabular}{|c|c|c|c|}
\hline $\begin{array}{c}\text { Variabel } \\
\text { Penelitian } \\
\end{array}$ & Definisi Variabel & Indikator & Skala \\
\hline $\begin{array}{l}\text { Tagline Iklan } \\
\qquad(\mathrm{x} 1)\end{array}$ & $\begin{array}{l}\text { Tagline berupa susunan kata atau frase } \\
\text { yang digunakan untuk merangkum atau } \\
\text { mengekspresi-kan tujuan dan semangat } \\
\text { merek. Kehadiran tagline bukanlah } \\
\text { sesuatu yang mutlak. Namun ia } \\
\text { mempunyai peran unik dan manfaat } \\
\text { khusus dalam mendukung komunikasi } \\
\text { merek. }\end{array}$ & $\begin{array}{l}\text { - Asli } \\
\text { - Dapat dipercaya } \\
\text { - Sederhana } \\
\text { - Dapat mempengaruhi } \\
\text { - Meyakinkan } \\
\text { - Mudah } \\
\quad \text { diigat/mengesankan } \\
\text { Darno (2016:42) }\end{array}$ & Likert \\
\hline $\begin{array}{l}\text { Brand } \\
\text { Ambasador } \\
\quad \text { (x2) }\end{array}$ & $\begin{array}{l}\text { Brand Ambassador adalah istilah } \\
\text { pemasaran untuk seseorang yang } \\
\text { dipekerjakan oleh sebuah organisasi atau } \\
\text { perusahaan untuk mempromosi-kan } \\
\text { produk atau jasa dalam kegiatan yang } \\
\text { dikenal sebagai branding. Brand } \\
\text { ambassador dimaksudkan untuk } \\
\text { mewujudkan identitas perusahaan dalam } \\
\text { penampilan, sikap, nilai-nilai dan etika. }\end{array}$ & $\begin{aligned} \text { - } & \text { Daya tarik } \\
\text { - } & \text { Kepercayaan } \\
\text { - } & \text { Keahlian } \\
& \text { Royan }(2014: 132)\end{aligned}$ & Likert \\
\hline $\begin{array}{c}\text { Brand } \\
\text { Awareness } \\
\text { (Y) }\end{array}$ & $\begin{array}{l}\text { Kesanggupan seorang calon pembeli } \\
\text { untuk mengenali, mengingat kembali } \\
\text { suatu merek sebagai bagian dari suatu } \\
\text { kategori produk tertentu. }\end{array}$ & $\begin{array}{l}- \text { Top of Mind } \\
-\quad \text { Brand Recall } \\
-\quad \text { Brand Recognition } \\
-\quad \text { Brand Unware } \\
\text { Kotler (2009:268) }\end{array}$ & Likert \\
\hline
\end{tabular}

\section{HASIL PENELITIAN DAN PEMBAHASAN}

\section{Karakteristik Responden}

Karakteristik responen berguna untuk mengetahui jawaban atas responden dilihat dari sudut identitas responden. Hal ini terkait dengan ketepatan sasaran yang dituju. Informasi yang dapat diperoleh antara lain adalah bedasarkan jenis kelamin, usia, informasi tempat tinggal, dan daerah asal. 
Tabel 2

Karakteristik Responden

\begin{tabular}{lcc}
\hline Uraian & Jumlah & Prosentase \\
Jenis Kelamin & & \\
\hline Perempuan & 62 & $64,6 \%$ \\
Laki-laki & 34 & $35,4 \%$ \\
Usia & & \\
$\quad$ <20 tahun & 15 & $15,6 \%$ \\
$20-25$ tahun & 52 & $54,2 \%$ \\
26-30 tahun & 23 & $24,0 \%$ \\
$>$ 30 tahun & 6 & $6,3 \%$ \\
Tempat Tinggal & & \\
Sendiri & 10 & $10.4 \%$ \\
Orang tua & 41 & $42.7 \%$ \\
Saudara & 16 & $16.7 \%$ \\
Kost/Kontrak & 29 & $30.2 \%$ \\
Daerah Asal & & $59,4 \%$ \\
Kota Makassar & 57 & $40,6 \%$ \\
Di luar Kota Makassar & 39 & \\
\hline
\end{tabular}

Sumber : Data Primer diolah, 2018

Pada hasil penelitian ini karakteristik responen yang pertama adalah jenis kelamin. Dari tabel di atas dapat diketahui bahwa responen terbanyak yang pernah mendengar tagline Axis Hits Bonus dan melihat Khan Theux sebagai brand ambassador Kartu Perdana Axis Hitz pada media elektronik dan cetak adalah perempuan yaitu sebanyak 62 dari 96 responden atau sebesar $64,6 \%$. Sedangkan untuk laki-laki sebanyak 34 dari 96 responen atau sebesar 35,4\%. Khan Theux sebagai brand ambassador kartu perdana Axis Hitz memang memiliki banyak penggemar di seluruh Indonesia, khususnya adalah kaun perempuan muda yang energik. Sehingga segala bentuk iklan dengan tagline yang disampaikan Khan Theux menjadi lebih mudah tersampaikan kepada kaum perempuan.
Data penelitian mengenai karakteristik responden bedasarkan usia diketahui usia terbanyak yang pernah mendengar tagline Axis Hitz Bonus dan melihat Khan Theux sebagai brand ambassador kartu perdana Axis Hitz pada media elektronik dan cetak adalah usia 20-25 tahun yaitu sebanyak 52 dari 96 responden atau 54,2\%. Sedangkan yang paling sedikit adalah usia $>30$ tahun yaitu sebanyak 6 dari 96 responden atau 6,3\%. Kartu perdana Axis Hitz ditargetkan bagi konsumen muda aktif dan kreatif sebagai konsumen yang selalu terhubung dengan handphone atau smartphone miliknya. Di sini peran kartu Axis menawarkan program berlangganan khusus untuk kaum muda yang memiliki intensitas tinggi dalam 
menggunakan handphone atau smartphone mereka.

Ditinjau dari hasil penelitian maka dapat diketahui bahwa karakteristik bedasarkan tempat tinggal perlu diketahui sebab lingungan dapat mempengaruhi dalam brand awareness konsumenya. Ada orang yang mengenal suatu brand tertentu karena informasi dari lingkungan keluarga atau saudara terdekatnya. Bedasarkan hasil penelitian diketahui responden terbanyak merupakan responden yang masih tinggal dengan orang tuanya, yaitu sebanyak 41 dari 96 responden atau $42,7 \%$. Sedangkan responden yang terendah adalah sebanyak 10 dari 96 responden atau 10,4\% merupakan responden yang tinggal sendiri. Dari analisis tempat tinggal tersebut dapat diartikan sebagian besar responden yang mendengar tagline Axis Hitz Bonus dan melihat Khan Theux sebagai brand ambassador kartu perdana Axis pada media elektronik dan cetak adalah mahasiswa yang tinggal bersama orang tuanya, mereka memiliki akses yang lebih mudah dalam menonton televisi atau berlangganan majalah karena ketersediaan media tersebut di rumahnya. Sedangkan responden yang ikut dengan saudaranya mereka lebih enggan untuk menonton TV atau membaca majalah di tempat tingga saudara mereka.

Karakteristik responden selanjutnya adalah bedasarkan daerah asal. karakteristik ini untuk mengetahui apakah pemasaran kartu perdana Axis di wilayah Makassar telah cukup besar atau tidak. Dari hasil penelitian menunjukkan sebanyak 57 dari 96 responden atau sebesar 59,4\% responden merupakan mahasiswa yang berdomisili di Kota Makassar. Sedangkan sisanya sebanyak 39 dari 96 responden atau sebesar 40,6\% responden berasal dari luar kota Makassar. Dari hasil ini dapat diketahui bahwa pemasaran kartu perdana Axis Hitz di kota Makassar cukup bagus. Sebagian besar responen pernah mendengar tagline Axis Hitz Bonus dan melihat Khan Theux sebagai brand ambassador Kartu Perdana Axis Hitz pada media elektronik dan cetak di Makassar. Dan responden yang berasal dari luar kota Makassar sebesar 40,6\% juga pernah mendengar dan menyaksikanya. Iklan dengan tagline dan brand ambassador yang terkenal dipadu dengan bahasa yang mudah dicerna melalui mediamedia yang sering disaksikan para responen seperti televisi, atau media cetak membuat baik responen asal kota Makassar maupun luar kota Makassar dapat tersampaikan dengan baik.

\section{Deskriptif Variabel Penelitian}

Deskripsi variabel penelitian digunakan untuk mengetahui gambaran masing-masing variabel penelitian yang disajikan dengan statistik deskriptif. Bedasarkan desain penelitian maka sumber informasi yang diperoleh dari jawaban responen dideskripsikan dalam bentuk nilai minimum, nilai maksimum, rata-rata dan standard deviasi. Perhitungan statistik deskriptif variabel penelitian dengan bantuan komputer dapat dilihat pada tabel 3 berikut ini : 
Tabel 3

Statistik Deskriptif

\begin{tabular}{lcccc}
\hline \multicolumn{1}{c}{ Statistik } & Min & Maks & Mean & Std Dev \\
\hline Tagline Iklan & 14 & 20 & 17,29 & 1,196 \\
Brand Ambassador & 9 & 15 & 12,33 & 1,167 \\
Brand Awareness & 10 & 24 & 18,71 & 2,388 \\
\hline
\end{tabular}

Data primer diolah, 2018

Berdasarkan hasil pengumpulan data yang disajikan pada tabel 4.2 diperoleh nilai minimal untuk variabel tagline iklan sebesar 14 dan nilai maksimum sebesar 20. Nilai minimal untuk variabel brand ambassador adalah sebesar 9 dan nilai maksimum sebesar 15. Sedangkan nilai minimal untuk brand awareness adalah 10 dan nilai maksimum sebesar 24 .

Untuk nilai mean tagline iklan adalah sebesar 17,29 brand ambassador 12,33 dan brand awareness sebesar 18,71. Selanjutnya standard deviasi dari tagline iklan adalah 1,196 brand ambassador 1,167 dan brand awareness sebesar 2,388. Dari ketiga analisis statistik deskriptif untuk nilai minimum, nilai maksimum, mean, dan standard deviasi menunjukkan bahwa variabel brand awareness memiliki nilai yang lebih besar dibandingkan dengan variabel tagline iklan dan brand awareness.

Selanjutnya dilakukan analisis deskriptif variabel penelitian dengan menggunakan capaian skor dari hasil pengolahan distribusi frekuensi, dimana setiap indikator pada variabel menggunakan Five-box Method, yaitu 0\%-20\% (sangat rendah),21\%-40\% (rendah) dan 41\%-60\% (sedang), 61\%$80 \%$ (tinggi) dan 81\%-100\% (sangat tinggi).

\section{Pembahasan}

Kartu perdana merupakan sebuah produk yang sangat penting bagi para pengguna telepon seluler atau (handphone). Perkembangan bisnis kartu perdana akhir-akhir ini telah menunjukkan suatu gejala, yaitu semakin banyak dan beragamnya kartu perdana yang ditawarkan oleh perusahaan dengan bermacam merek, fitur dan fasilitas yang semakin lengkap dengan strategi pemasaran yang unik dan inovatif.

Kebanyakan pengguna telepon seluler di indonesia saat ini adalah para remaja yang tidak bisa lepas dari kebutuhan menggunakan fitur-fitur yang tersedia pada telepon selulernya, mulai dari sekedar mengirim pesan singkat, telepon, hingga menggunakan layanan internet seperti membuka situs media sosial hingga kebutuhan informasi melalui web-web yang tersedia saat ini.

Strategi pemasaran dengan promosi yang dilakukan oleh Kartu Axis melibatkan artis muda berbakat yang terkenal di kalangan anak muda atau remaja Indonesia. Penggunaan artis muda pada iklan ini diharapkan dapat menarik perhatian kalangan muda sehingga mereka dapat dengan mudah mengingat produk sehingga meningkatkan brand awareness para anak muda dan masyarakat akan produk kartu perdana Axis Hitz. Iklaniklan Axis dapat dikatakan memanfaatkan tagline dan brand ambassador yang diharapkan mampu meningkatkan brand awareness masyarakat, khususnya kalangan muda 
atau remaja yang kreatif, dan inovatif aktif dalam menggunakan telepon seluler mereka.

Bedasarkan hasil pengujian model yang telah dilakukan diketahui besarnya kolerasi antara variabel tagline dan brand ambassador terhadap brand awareness konsumen kartu perdana Axis Hitz sebesar 0.806. Artinya sebesar $80,6 \%$ tagline dan brand ambassador berpengaruh terhadap brand awareness konsumen kartu perdana Axis Hitz dan sisanya sebesar $19,4 \%$ dipengaruhi oleh faktor yang lain. $80,6 \%$ pengaruh tagline dan brand ambassador terhadap brand awareness konsumen produk kartu perdana Axis Hitz dapat diartikan adanya tagline dan brand ambassador dalam iklan suatu produk mampu mempengaruhi brand awareness meskipun pengaruh yang diberikan tidak sepenuhnya berdampak pada brand awareness konsumen kartu perdana Axis Hitz.

Hasil pengkategorian yang telah dijelaskan sebelumnya menunjukkan hasil bahwa responden sebagian besar menilai adanya tagline dan brand ambassador cukup penting dalam mempengaruhi brand awareness konsumen kartu perdana Axis. Pernyataan ini didukung pula dari hasil pengujian hipotesis yang menyatakan variabel tagline dan brand ambassador berpengaruh positif dan signifikan terhadap brand awareness konsumen kartu perdana Axis baik secara simultan maupun parsial.

\section{Pengaruh penggunaan tagline terhadap brand awareness}

Nuradi dkk. (2012: 56) tagline adalah kalimat singkat sebagai penutup teks inti yang menyimpulkan secara singkat tujuan komunikasi suatu iklan. Tagline ini merupakan suatu ungkapan pendek berisi pesan yang padat dan mudah diingat. Tagline ini bisa disamakan dengan slogan, atau jargon dalam iklan. Penggunaan tagline ini adalah untuk memperkuat kemampuan iklan dalam mengeksekusi (mencapai sasarannya) yaitu mempengaruhi konsumen untuk mengingat hingga menggunakan produk yang diiklankan. Menurut Darno (2014;42) keberhasilan tagline iklan dalam menjalankan fungsinya dapat diukur dengan 6 indikator yaitu "asli, dapat dipercaya, sederhana, dapat mempengaruhi, meyakinkan, dan mudah diingat/mengesankan".

Tagline digunakan sebagai pernyataan standard yang mudah diterima di benak konsumen yang dibuat untuk membuat konsumen mengenali produk dengan cepat tentang kelebihan produk, hingga mengingatkan kembali kepada konsumen akan eksistensi produk.

Bedasarkan pernyataan-pernyataan tersebut, tagline yang dibuat oleh Axis untuk produk-produknya dalam pemasaranya melalui media elektronik maupun media cetak, diharapkan telah sesuai dan dapat dengan mudah diterima oleh masyarakat luas di seluruh Indonesia. Penggunaan tagline "Axis Hitz Bonus" menjadi ciri khas kartu perdana Axis Hitz yang berusaha mengkomunikasikan nilai-nilai kelebihan yang dimiliki.

Axis semakin digemari oleh masyarakat berkat adanya promopromo paket yang di tawarkan sangatlah murah. Seperti paket sms yang super murah ini mampu menarik minat pada kalangan anak muda untuk menggunakan layanan Axis. Dari paket internet juga tak kalah murah ini juga yang membuat masyarakat menggunakan Layanan Axis, terlebih lagi anak muda yang jampir setiap hari melakukan aktifitas di dunia Internet pasti memilih layanan Axis sebagai 
operator seluler mereka. Bukan hanya paket yang murah , pada kklannya Axis Juga selalu menyuguhkan tema yang unik dan lucu, itu merupakan salah satu strategi jitu untuk mampu menarik minat konsumen dan Itu terbukti.

Pada tahun 2017 Axis kembali meluncurkan iklan terbaru dengan tagline AXIS HITZ BONUS. Pada Iklan tersebut yang menjadi perhatian adalah Parody Goblin dan Macan Cisewu ini benar benar unik dan lucu.

\section{Pengaruh brand ambassador terhadap brand awareness}

Selain faktor tagline yang mampu mempengaruhi brand awareness akan produk kartu perdana Axis, faktor brand ambassador diharapkan mampu turut serta mempengaruhi brand awareness konsumen saat melihat brand ambassador dalam setiap iklan yang dibintanginya.

Menurut Shimp (2003:455) brand ambassador adalah pendukung iklan atau juga yang dikenal sebagai bintang iklan yang mendukung produk yang diiklankan. Para brand ambassador diharapkan menjadi juru bicara merek agar cepat melekat di benak konsumen, sehingga konsumen mau membeli merek tersebut. Selain itu, selebriti bisa juga digunakan sebagai alat yang tepat untuk mewakili segmen pasar yang dibidik.

Daya tarik Khan Theux digunakan sebagai bintang iklan dalam produk kartu perdana Axis Hitz, diharapkan sesuai dengan segmen pasar kartu Axis yaitu kalangan remaja ke atas yang aktif dalam menggunakan layanan kartu perdana seperti mengirim pesan singkat, telepon, browsing melalui internet, dan menggunakan media-media sosial. Khan Theux yang berprofesi sebagai artis film dan bintang iklan tentunya memiliki daya tarik baik secara fisik maupun keahlianya di dunia hiburan.

Konsep daya pikat ini juga sesuai dengan indikator kesuksesan seorang brand ambassador dalam melakukan tugasnya dalam strategi pemasaran kartu Axis. Selain daya tarik, ada indikator lain yang harus dipenuhi oleh brand ambassador seperti keahlianya dalam berkomunikasi, kepercayaan yang dibuat oleh brand ambassador, dan kekuatan personal yang dimiliki untuk menimbulkan kesan yang dalam kepada para konsumen yang melihat brand ambassador saat menawarkan produknya.

Pada Hasil penelitian ini menunjukkan bahwa variabel brand ambassador berpengaruh secara positif dan signifikan terhadap brand awareness konsumen. Hal ini menunjukan komponen yang ada pada brand ambassador Khan Theux yang digunakan pada iklan produk kartu perdana Axis mampu menarik hari kalangan remaja.

\section{Pengaruh tagline dan brand ambassador terhadap brand awareness}

Hasil penelitian menunjukkan bahwa "tagline dan brand ambassador secara bersama-sama (simultan) berpengaruh positif terhadap brand awareness. Dengan kata lain bisa disimpulkan bahwa jika tagline dan brand ambassador meningkat, maka akan berdampak positif pula terhadap brand awareness produk kartu Axis.

Dari hasil penelitian juga diketahui nilai koefisien determinasi sebesar 0.806, yang artinya bahwa tagline dan brand ambassador memengaruhi brand awareness 80,6\%, dan sisanya sebesar 19,4\% dipengaruhi oleh faktor lain di luar variabel penelitian ini. 


\section{KESIMPULAN}

Bedasarkan hasil analisis yang dilakukan, maka kesimpulan yang dapat dikemukakan dalam penelitian ini adalah sebagai berikut:

1. Terdapat pengaruh yang positif dan signifikan antara tagline terhadap brand awareness produk kartu perdana Axis. Hal ini ditunjukan dari hasil uji t hitung sebesar 2,385 dengan signifikansi 0.000. Semakin bagus tagline dalam sebuah iklan produk maka akan meningkatkan brand awareness produknya, begitu pula sebaliknya.

2. Terdapat pengaruh positif dan signifikan antara brand ambassador terhadap brand awareness produk kartu perdana Axis. Hal ini ditunjukan dari hasil uji t hitung sebesar 1,803 deangan signifikansi 0.000. Semakin bagus brand ambassador dalam mempromosikan produk maka akan semakin meningkatkan brand awareness produknya, begitu pula sebaliknya.

3. Terdapat pengaruh yang positif dan signifikan antara tagline dan brand ambassador terhadap brand awareness produk kartu Axis. Hal ini ditunjukan dari hasil uji $\mathrm{F}$ hitung sebesar 4,731 dengan nilai signifikan 0.000. Semakin bagus tagline yang digunakan dalam iklan, dan semakin bagus brand ambassador yang mampu mempromosikan produknya, maka akan mempengaruhi brand awareness produk kartu perdana Axis.

\section{DAFTAR PUSTAKA}

Aaker, A. .D. 2011. Manajemen Ekuitas Merek. Alih bahasa oleh Aris Ananda .Mitra Utama, Jakarta.
Arikunto,S, 2010. Prosedur Penelitian. Suatu Pendekatan Praktik. Rineka Cipta, Jakarta.

Arifin, Z, 2012. Penenlitian Pendidikan Metode dan Paradigma Baru. Bandung: Remaja Rosda Karya

Azwar,2012. Metode Penelitian. Pustaka Pelajar, Yogyakarta.

Darno. 2016. Efektifitas Tagline dalam Meningkatkan Brand Awareness. Skripsi. Universitas Negeri Malang

Durianto, D, dkk. 2014. Strategi Menaklukkan Pasar. PT. Gramedia Pustaka Utama, Jakarta.

Ferdinand,A, 2006. Metode Penelitian Manajemen: Pedoman Penelitian Untuk Penulisan Skripsi, Tesis dan Disertasi Ilmu Manajemen. Badan Penerbit Universitas Diponegoro. Semarang

Ghozali, I, 2006. Aplikasi Analisis Multivariate dengan Program SPSS. (Edisi Ke 4). Badan Penerbit Universitas Diponegoro, Semarang.

Ismiati,N, 2014. Slogan dan Tagline Senjata Pamungkas Iklan. CAKRAM Komunikasi.

Keller, K.L, 2012., Strategic Brand Management

Building,Measuring, And

Managing Brand Equity, Second Edition, Pearson Prentice Hal , New Jersey.

Kotler, P, 2009 Manajemen Pemasaran: Analisis, Perencanaan, Implementasi, dan Pengendalian. Edisi Kedelapan, Salemba Empat, Jakarta.

Kotler, P, dan Keller, K.L, 2012. Manajemen Pemasaran Jilid 1, edisi Ketiga Belas, Terjemahan Bob Sabran, MM. Penerbit Erlangga, Jakarta.

Nuradi, dkk,2012. Kamus Istilah Periklanan Indonesia. Jakarta. 
Royan.F.M, 2014. Sales Force

(Meningkatkan Penjualan

Dengan Rancangan Bangun

Sales Force Effective), Penerbit Andi, Yogyakarta.

Sadat,A.M, M,2009. Brand Belief: Strategi

Membagun Merek Berbasis

Keyakinan.Salemba

Empat:Jakarta.

Schultz,D.E.\& Bames, B.E. 2009.

Strategic Brand Communication

Campaigns. Illionis: NTC

Business Books.

Setiaji, B, 2014, Panduan Riset dengan

Pendekatan Kuantitatif.

Muhammadiyah University

Press. Surakarta.

Sigit,S, 2010. Creative Advertising. PT Elex Media Komputindo, Jakarta.

Sumarni dan Wahyuni, 2006,

Metodologi Penelitian dan

Bisnis, Penerbit Andi,

Yogyakarta.

Susanto,A.B, dan Wijanarko,H, 2014, Power Branding, Quantum, . Bisnis dan Manajemen, Jakarta.

Shimp, T.A,2003, Periklanan Promosi Aspek Tambahan Komunikasi Pemasaran Terpadu Jilid 5, diterjemaahkan oleh RevyaniSyahrian dan Dyah Anikasari, Erlangga, Jakarta.

Sugiyono. 2012. Metode Penelitian Kualitatif Dan R\&D. CV. Alfabeta. Bandung.

Suryabrata,S, 2008. Metodologi Penelitian. Raja Grafindo Persada. Jakarta

Swastha,B.D.H dan Irawan, 2010. Manajemen Pemasaran Modern, Edisi Kedua, Cetakan Ketigabelas, Liberty Offset, Yogyakarta.

Sumarwan, U, 2013.Perilaku Konsumen. Ghalia Indonesia. Jakarta. 